\title{
Mean Performance of Fifty Genotypes of Fennel (Foeniculum vulgare Mill.) for Yield and Yield Attributing Traits
}

\author{
R.K. Telugu*, S.K. Tehlan, M. Srikanth and N.C. Mamtha \\ Department of Vegetable Science, CCS Haryana Agricultural University, Hisar-124004 \\ (Haryana), India \\ *Corresponding author
}

\section{A B S T R A C T}

\begin{tabular}{|c|c|}
\hline $\begin{array}{l}\text { Key wo r d s } \\
\text { Fennel, Range, } \\
\text { Variability, Yield } \\
\text { and Yield } \\
\text { attributing traits }\end{array}$ & $\begin{array}{l}\text { Fifty Fennel (Foeniculum vulgare Mill.) genotypes collected from different agro - climatic } \\
\text { zones (Haryana, Rajasthan, Gujarat, Uttar Pradesh and Bihar) for their yield and yield } \\
\text { attributing traits on pooled data (Rabi seasons of } 2015-16 \text { and 2016-17) recorded that there } \\
\text { is a wide range of variability for the traits under study. The maximum plant height was } \\
\text { recorded in HF-173 }(184.90 \mathrm{~cm}) \text {, whereas the minimum plant height was recorded in JF- } \\
406(118.07 \mathrm{~cm}) \text {. The highest number of primary branches per plant and secondary }\end{array}$ \\
\hline Article Info & $\begin{array}{l}\text { branches per plant were recorded in HF-167 (12.70) and HF-168 (24.60) respectively. } \\
\text { Early days to } 50 \% \text { flowering was recorded in HF-179 (110.03). The maximum umbels per }\end{array}$ \\
\hline $\begin{array}{l}\text { Accepted: } \\
\text { 04 December } 2018 \\
\text { Available Online: } \\
\text { 10 January } 2019\end{array}$ & $\begin{array}{l}\text { plant }(71.40) \text { and biological yield per plant }(311.95 \mathrm{~g}) \text { was recorded in genotype HF-169. } \\
\text { And the maximum umbellates per umbel }(33.37) \text { seeds per umbellate }(25.66) \text {, seeds per } \\
\text { umbel }(851.83) \text {, seed yield per plant }(73.17 \mathrm{~g}) \text {, seed yield per ha }(65.85 \mathrm{Q}) \text {, harvest index } \\
(25.17 \%) \text { and test weight }(9.51 \mathrm{~g}) \text { were recorded in genotype HF-171. }\end{array}$ \\
\hline
\end{tabular}

\section{Introduction}

Fennel commonly known as 'saunf', an open pollinated spice crop of temperate and subtropical regions belongs to the family Umbelliferae (Apiaceae), has originated from Mediterranean region, where its high degree of genetic variability persists (Miranldi, 1999). It is a diploid species with chromosome number $2 \mathrm{n}=22$. Fennel seed consists of $6.3 \%$ moisture, $9.5 \%$ protein, $10 \%$ fat, $13.4 \%$ minerals, $18.5 \%$ fibre and $42.3 \%$ carbohydrates and also vitamins like vitamin $\mathrm{C}$, thiamin, riboflavin, niacin and minerals like calcium, phosphorous, iron, sodium and potassium (Bhunia et al.,, 2005). The fennel seeds are aromatic, stimulant and carminative, used in diseases of cholera, bile disturbances, nervous disorders, constipation and dysentery and also used for control of diseases attacking lungs, chest, spleen and kidney stones and menopausal problems (Mohamed and Abdu, 2004). For crop improvement program presence of genetic variability in to the population is very important as it provide chance to pick the genotype having desirable trait for improvement and it also gives wide range of options to improve trait of interest. So, the evaluation of genotypes is important for further crop improvement program. 


\section{Materials and Methods}

The study was conducted at Research Farm of the Department of Vegetable Science, CCCSHAU, Hisar (Haryana) during the Rabi seasons of 2015-16 and 2016-17. The experimental material consisted of fifty genotypes of fennel in randomized block design with three replications. Each genotype is planted at a spacing of $50 \mathrm{~cm} \times 20 \mathrm{~cm}$ (single row of $3.0 \mathrm{~m}$ length for each genotype). The pooled data on thirteen morphological and yield attributing traits was taken in five plants which were tagged at random in all three replications to record the pooled data and analyzed by the standard statistical methods.

\section{Results and Discussion}

The results of the present investigation are presented in the Table 1. The plant height ranged from 118.07 to $184.90 \mathrm{~cm}$ with an overall mean of $149.28 \mathrm{~cm}$. The maximum plant height was recorded in the genotypes HF-173 $(184.90 \mathrm{~cm})$ followed by HF-171 $(183.04 \mathrm{~cm})$, HF-169 $(177.02 \mathrm{~cm})$, NDF-42 $(169.77 \mathrm{~cm})$, HF-168 $(169.22 \mathrm{~cm})$ and NDF$28(166.94 \mathrm{~cm})$ while, the minimum plant height was recorded in the genotype JF-406 $(118.07 \mathrm{~cm})$.

Primary branches per plant varied from 5.08 to 12.70 with overall mean 9.11. The genotype HF167 (12.70) recorded maximum number of primary branches per plant followed by HF- 168 (12.55), HF-169 (12.10), HF-171 (12.08), HF173 (11.77) and HF-174 (11.20). The minimum number of primary branches per plant was recorded in the genotype JF-12 (5.08).

Secondary branches per plant varied from 10.74 to 24.60 with an overall mean 17.00. The maximum number of secondary branches per plant was recorded in the genotypes HF168 (24.60) followed by HF-169 (22.07), HF-
167 (21.23), HF-171 (20.90) and HF-173 (20.27). And minimum number of secondary branches per plant was recorded in the genotype JF- 12 (10.74).

Days to $50 \%$ flowering exhibited in the population and it ranged from 107.03 days (HF-179) to 125.80 days (RF-38) with an overall mean of 115.88 days. The minimum number of days to $50 \%$ flowering by genotypes like HF-179, HF-178, HF-168, HF169, HF-170, HF-171, HF-167, HF-182, HF173 and HF-180 are considered as early flowering whereas maximum number of days taken to $50 \%$ flowering by genotypes like RF38, HF-176, RF-21，JK/RM/AF-24, JF-406 and $\mathrm{JK} / \mathrm{RM} / \mathrm{AF}-13$ are considered as late.

Umbels per plant and the means for umbels per plant ranged from 23.67 to 71.40 with an overall mean of 44.74. The maximum numbers of umbels per plant was recorded in genotype HF-169 (71.40) followed by HF-171 (69.93), HF-167 (69.10), HF-168 (66.67) and HF-173 (62.63) and minimum number of umbels per plant was recorded in JF-12 (23.67).

Umbellates per umbel recorded ranged from 17.93 to 33.37 with an average of 25.26. Maximum number of umbellates per umbel was recorded in HF-171(33.37) followed by HF-169 (32.95), HF-168 (32.55) HF-173 (31.92) and HF-167 (29.39), while, the minimum number of umbellates per umbel was observed in JF-12 (17.93).

Seeds per umbellate ranged from 14.93 to 25.60 with an overall mean of 19.52. The maximum seeds per umbellate was observed in genotype HF-171(25.60) followed by HF168 (24.17), HF-167 (23.67), HF-169 (22.78), NDF-28 (22.73), HF-173 (22.65) and HF-180 (22.57), while minimum number of seeds per umbellate was shown by JF-12 (14.93). 
Table.1 Mean values of different characters of 50 fennel genotypes- pooled means of two years

\begin{tabular}{|c|c|c|c|c|c|c|c|c|c|c|c|c|c|}
\hline Genotypes & $\begin{array}{c}\text { PH } \\
(\mathbf{c m})\end{array}$ & PBP & SBP & DFF & UPP & UTPU & SPUT & SPU & $\begin{array}{c}\text { SYPP } \\
\text { (g) }\end{array}$ & SYPH(Q) & $\begin{array}{c}\text { BYPP } \\
\text { (g) }\end{array}$ & $\begin{array}{c}\text { HI } \\
(\%)\end{array}$ & $\begin{array}{c}\text { TW } \\
\text { (g) }\end{array}$ \\
\hline HF-162 & 143.64 & 7.95 & 15.44 & 112.66 & 43.44 & 23.12 & 17.87 & 415.20 & 34.03 & 30.63 & 236.72 & 14.44 & 5.19 \\
\hline HF-163 & 141.27 & 7.67 & 15.93 & 114.47 & 36.47 & 24.83 & 18.20 & 452.62 & 38.84 & 34.95 & 254.09 & 15.30 & 5.38 \\
\hline HF-164 & 151.27 & 7.52 & 17.40 & 113.63 & 41.07 & 24.97 & 17.53 & 437.94 & 42.73 & 40.73 & 250.67 & 17.23 & 6.31 \\
\hline HF-165 & 137.62 & 9.57 & 16.97 & 115.97 & 45.50 & 24.45 & 18.78 & 460.47 & 40.80 & 36.72 & 265.93 & 15.35 & 5.55 \\
\hline HF-166 & 150.70 & 9.10 & 16.23 & 115.77 & 44.37 & 23.07 & 18.70 & 431.36 & 42.67 & 38.40 & 263.58 & 16.20 & 5.68 \\
\hline HF-167 & 163.23 & 12.70 & 21.23 & 111.40 & 69.10 & 29.39 & 23.67 & 694.97 & 63.40 & 53.45 & 283.92 & 22.38 & 7.43 \\
\hline HF-168 & 164.71 & 12.55 & 24.60 & 110.10 & 66.67 & 32.55 & 24.17 & 788.37 & 67.67 & 61.83 & 293.18 & 23.13 & 8.53 \\
\hline HF-169 & 177.02 & 12.10 & 22.07 & 110.20 & 71.40 & 32.95 & 22.78 & 825.43 & 70.10 & 62.76 & 311.95 & 22.51 & 9.27 \\
\hline HF-170 & 158.01 & 9.25 & 18.70 & 110.37 & 47.70 & 23.80 & 18.33 & 436.80 & 43.40 & 39.72 & 256.70 & 16.99 & 6.01 \\
\hline HF-171 & 183.04 & 12.08 & 20.90 & 111.27 & 69.93 & 33.37 & 25.60 & 851.83 & 73.17 & 65.85 & 290.65 & 25.17 & 9.51 \\
\hline HF-172 & 151.37 & 9.10 & 18.93 & 115.87 & 42.87 & 23.75 & 18.80 & 445.90 & 40.73 & 39.15 & 252.76 & 16.19 & 5.79 \\
\hline HF-173 & 184.90 & 11.77 & 20.27 & 111.90 & 62.63 & 31.92 & 22.65 & 725.13 & 66.17 & 59.55 & 277.11 & 23.84 & 8.22 \\
\hline HF-174 & 161.21 & 11.20 & 17.90 & 114.90 & 43.83 & 25.13 & 17.93 & 450.10 & 47.14 & 38.35 & 241.66 & 19.56 & 6.41 \\
\hline HF-175 & 164.35 & 10.15 & 16.97 & 113.67 & 46.60 & 24.97 & 17.77 & 442.16 & 41.73 & 37.56 & 250.88 & 16.74 & 6.51 \\
\hline HF-176 & 148.50 & 9.95 & 17.87 & 124.70 & 46.92 & 25.95 & 18.59 & 480.52 & 38.97 & 42.82 & 255.24 & 15.37 & 6.55 \\
\hline HF-177 & 158.05 & 9.30 & 16.77 & 114.03 & 41.57 & 25.27 & 18.65 & 471.53 & 39.85 & 35.88 & 264.97 & 15.04 & 5.84 \\
\hline HF-178 & 158.11 & 10.20 & 16.57 & 107.17 & 44.84 & 24.64 & 17.90 & 442.23 & 44.37 & 41.31 & 253.04 & 17.59 & 6.03 \\
\hline HF-179 & 160.30 & 10.40 & 17.30 & 107.03 & 43.40 & 25.83 & 18.18 & 470.22 & 39.43 & 35.49 & 252.94 & 15.65 & 6.01 \\
\hline HF-180 & 162.51 & 10.47 & 17.93 & 112.43 & 56.17 & 28.03 & 22.57 & 632.93 & 51.57 & 46.41 & 272.46 & 20.77 & 7.16 \\
\hline HF-182 & 169.22 & 10.38 & 17.83 & 111.50 & 53.87 & 27.72 & 21.59 & 599.94 & 51.49 & 46.34 & 273.67 & 20.35 & 7.08 \\
\hline NDF-28 & 166.94 & 9.97 & 18.24 & 112.77 & 47.83 & 28.57 & 22.73 & 651.61 & 51.81 & 46.63 & 260.04 & 19.93 & 7.25 \\
\hline NDF-38 & 149.90 & 11.05 & 18.84 & 119.03 & 53.64 & 25.92 & 21.35 & 555.62 & 55.77 & 50.19 & 259.36 & 21.66 & 7.37 \\
\hline NDF-39 & 149.90 & 10.67 & 15.63 & 113.07 & 53.03 & 27.15 & 19.13 & 521.89 & 47.53 & 38.28 & 246.36 & 19.37 & 5.98 \\
\hline NDF-41 & 148.33 & 8.25 & 16.57 & 116.73 & 44.23 & 26.65 & 20.33 & 545.20 & 46.00 & 44.68 & 239.56 & 19.20 & 6.23 \\
\hline NDF-42 & 169.77 & 10.80 & 17.40 & 119.77 & 44.84 & 25.13 & 21.30 & 533.55 & 42.80 & 47.76 & 236.79 & 18.18 & 6.76 \\
\hline NDF-43 & 158.39 & 8.67 & 16.57 & 119.20 & 41.23 & 26.37 & 20.80 & 550.50 & 44.53 & 41.76 & 249.34 & 18.06 & 6.40 \\
\hline NDF-44 & 146.04 & 9.59 & 16.97 & 116.13 & 45.27 & 26.05 & 20.08 & 524.41 & 43.20 & 40.38 & 242.49 & 17.86 & 6.19 \\
\hline JF-12 & 120.96 & 5.08 & 10.74 & 112.97 & 23.67 & 17.93 & 14.93 & 268.90 & 19.04 & 17.13 & 210.71 & 9.06 & 3.47 \\
\hline
\end{tabular}




\begin{tabular}{|c|c|c|c|c|c|c|c|c|c|c|c|c|c|}
\hline JF-382-2 & 120.13 & 5.77 & 12.27 & 118.27 & 33.80 & 22.50 & 17.40 & 393.47 & 28.87 & 27.06 & 231.54 & 12.48 & 4.55 \\
\hline JF-406 & 118.07 & 6.88 & 13.78 & 119.10 & 27.43 & 19.58 & 16.27 & 319.00 & 21.90 & 20.52 & 224.81 & 9.75 & 3.69 \\
\hline JF-421 & 131.10 & 6.52 & 14.37 & 120.40 & 33.80 & 22.47 & 18.20 & 407.82 & 27.97 & 25.17 & 241.67 & 11.72 & 4.42 \\
\hline JF-494 & 124.83 & 9.18 & 16.10 & 119.73 & 29.90 & 20.15 & 16.47 & 333.19 & 23.67 & 21.30 & 240.04 & 9.87 & 3.84 \\
\hline JF-533-2 & 130.54 & 6.84 & 14.63 & 119.80 & 35.20 & 23.08 & 17.27 & 400.16 & 26.43 & 23.79 & 235.85 & 11.21 & 4.23 \\
\hline JF-582 & 130.91 & 8.49 & 16.77 & 115.50 & 41.10 & 23.40 & 18.20 & 427.32 & 32.33 & 28.18 & 246.02 & 13.13 & 5.17 \\
\hline JK-/RM/AF-7 & 146.39 & 7.33 & 15.93 & 118.90 & 45.37 & 27.59 & 21.37 & 591.91 & 49.90 & 44.91 & 271.11 & 19.99 & 6.46 \\
\hline JK-/RM/AF-9 & 149.87 & 8.65 & 15.60 & 119.40 & 47.19 & 26.72 & 20.82 & 557.68 & 50.80 & 45.72 & 275.05 & 19.88 & 6.56 \\
\hline $\begin{array}{l}\text { JK-/RM/AF- } \\
13\end{array}$ & 157.52 & 8.97 & 17.33 & 120.00 & 47.67 & 26.73 & 20.43 & 544.63 & 47.02 & 42.31 & 258.96 & 18.19 & 6.44 \\
\hline $\begin{array}{l}\text { JK-/RM/AF- } \\
19\end{array}$ & 153.17 & 8.99 & 15.37 & 116.77 & 42.57 & 23.83 & 21.52 & 513.21 & 42.40 & 40.17 & 261.71 & 16.25 & 6.03 \\
\hline $\begin{array}{l}\text { JK-/RM/AF- } \\
24\end{array}$ & 147.13 & 8.07 & 16.00 & 121.00 & 41.73 & 25.07 & 18.33 & 461.52 & 37.40 & 30.63 & 258.57 & 14.57 & 5.88 \\
\hline RF-21 & 127.07 & 8.55 & 16.53 & 124.17 & 31.70 & 20.93 & 18.90 & 397.64 & 29.74 & 26.76 & 249.72 & 11.93 & 4.82 \\
\hline RF-38 & 122.87 & 8.02 & 16.13 & 125.80 & 34.30 & 22.30 & 18.34 & 410.10 & 28.37 & 25.53 & 253.43 & 11.22 & 4.42 \\
\hline RF-54 & 149.95 & 8.02 & 16.37 & 118.23 & 37.30 & 20.63 & 17.74 & 366.13 & 35.77 & 35.28 & 246.04 & 14.61 & 5.45 \\
\hline RF-57 & 150.63 & 8.38 & 16.47 & 119.80 & 27.50 & 20.13 & 16.87 & 340.42 & 25.10 & 22.59 & 253.11 & 9.92 & 4.23 \\
\hline GF-11 & 146.67 & 7.32 & 15.40 & 113.37 & 39.07 & 24.38 & 20.97 & 513.02 & 39.27 & 35.34 & 266.32 & 14.77 & 5.47 \\
\hline GF-12 & 141.41 & 7.85 & 17.27 & 115.87 & 44.97 & 26.22 & 19.00 & 501.16 & 43.13 & 40.26 & 275.13 & 15.68 & 6.09 \\
\hline HF-33 & 136.23 & 8.33 & 17.87 & 113.70 & 47.97 & 26.73 & 19.10 & 513.73 & 46.47 & 44.73 & 257.22 & 18.09 & 6.26 \\
\hline HF-39 & 140.05 & 8.69 & 16.97 & 115.03 & 48.53 & 24.83 & 20.67 & 514.98 & 44.60 & 40.14 & 250.78 & 17.83 & 6.10 \\
\hline PF-35 & 144.72 & 9.82 & 16.37 & 118.27 & 44.20 & 25.13 & 20.27 & 511.88 & 44.00 & 40.89 & 252.58 & 17.43 & 6.34 \\
\hline GF-2 & 142.57 & 7.90 & 15.80 & 115.57 & 39.50 & 24.97 & 18.42 & 461.15 & 41.10 & 36.99 & 265.99 & 15.54 & 5.71 \\
\hline R.sourbha & 153.13 & 9.53 & 16.00 & 116.70 & 44.34 & 26.33 & 18.63 & 492.68 & 43.40 & 40.56 & 242.89 & 17.87 & 6.26 \\
\hline Overall mean & 149.28 & 9.11 & 17.00 & 115.88 & 44.74 & 25.26 & 19.52 & 501.60 & 42.77 & 39.07 & 256.11 & 16.70 & 6.05 \\
\hline SE(m) & 3.84 & 0.24 & 0.61 & 1.08 & 1.24 & 0.90 & 0.71 & 10.60 & 2.12 & 1.22 & 6.26 & 0.81 & 0.13 \\
\hline C.D $5 \%$ & 10.79 & 0.68 & 1.21 & 3.05 & 3.48 & 2.54 & 1.99 & 29.81 & 5.96 & 3.42 & 17.61 & 2.27 & 0.37 \\
\hline CV (\%) & 4.45 & 4.62 & 4.38 & 1.62 & 4.79 & 6.18 & 6.28 & 3.66 & 8.59 & 5.40 & 4.24 & 8.39 & 3.80 \\
\hline
\end{tabular}

PH; Plant Height, PBP; Primary Branches per Plnat. SBP; Secondary Branches per Plant, DFF; Days to 50 \% Flowering, UPP; Umbels per Plant, UTPU; Umbellates per Umbel, SPUT; Seeds per Umbellate SPU; Seeds per Umbel, SYPP; Seed Yield per Plant, SYPH; Seed Yield Per ha, BYPP; Biologiclal Yield per Plant, HI; Harvest Index, TW; Test Weight 
The seeds per umbel ranged from 268.90 to 851.83 with an overall mean of 501.60. The maximum number of seeds per umbel was observed in genotype HF-171 (851.83) followed by HF- 169 (825.43), HF-168 (788.37), HF-173 (725.13) and HF-167 (694.97). And minimum number of seeds per umbel observed in JF-12 (268.90).

Seed yield per plant ranged from $19.04 \mathrm{~g}$ to $73.17 \mathrm{~g}$ with an overall mean of $42.77 \mathrm{~g}$. The maximum seed yield per plant was recorded in genotype HF-171 (73.17 g) followed by HF-169 (70.10), HF-168 (67.67), HF-173 (66.17) and HF-167 (63.40), while the minimum seed yield per plant recorded was in JF-12 (19.04g).

Seed yield per ha ranged from $17.13 \mathrm{Q}$ to 65.85 Q with an overall mean of 39.07 Q. The maximum seed yield per ha was recorded in genotype HF-171(65.85 Q) followed by HF169 (62.76), HF-168 (61.83), HF-173 (59.55) and HF- 167 (53.45). And minimum seed yield per ha was recorded in JF-12 (17.13 Q).

The biological yield per plant ranged from $210.71 \mathrm{~g}$ to $311.95 \mathrm{~g}$ with an overall mean of $256.11 \mathrm{~g}$. The maximum numbers of biological yield per plant was recorded in genotype HF-169 (311.95 g) followed by HF168 (293.18), HF-171 (290.65) HF- 167 (283.92), HF-173 (277.11), GF-12 (275.13), JK/RM/AF-9 (275.05) and HF-182 (273.67), while the minimum number of biological yield per plant was recorded in JF-12 (210.71 g).

Harvest index ranged from $9.06 \%$ to $24.16 \%$ and the overall mean value was calculated to be $16.70 \%$. The maximum harvest index was recorded in genotype HF-171(24.16 \%) followed by HF- 173 (23.84 \%), HF-168 (23.13\%), HF-169 (22.51\%), HF-167 (22.38 $\%)$ and NDF-38 (21.66 \%). And minimum harvest index was recorded in JF-12 (9.06 \%).
Test weight ranged from $3.47 \mathrm{~g}$ to $9.51 \mathrm{~g}$ and the overall mean was $6.05 \mathrm{~g}$. The maximum test weight was recorded in genotype HF-171 $(9.51 \mathrm{~g})$ followed by HF-169 (9.27 g), HF168 (8.53 g), HF-173 (8.22 g), HF-167 (7.43 g) and NDF-38 (7.37 g). And minimum test weight was recorded in JF-12 (3.47 g).

From the study we can draw conclusion that the mean performance of all thirteen characters under study revealed a great range of mean values, which concludes that there is a wide genetic variability among the genotypes for the traits like plant height $(\mathrm{cm})$, primary branches per plant, secondary branches per plant, days to $50 \%$ flowering, umbels per plant, Umbellates per umbel, seeds per umbellate, seeds per umbel, seed yield per plant $(\mathrm{g})$, seed yield per ha $(\mathrm{Q})$, biological yield per plant $(\mathrm{g})$, harvest index (\%) and test weight (g). Therefore there is a scope for selection of genotypes with desirable component characters in crossbreeding program. These results corroborate the findings of Singh and Mittal (2002), Singh et al., (2004), Patel et al., (2008), Yogi et al., (2013), Sengupta et al., (2014), Ghanshyam et al., (2015) and Mamatha et al., (2017).

\section{References}

Bhunia, S. R., Chauhan, R. P. S. and Yadav, B. S. 2005. Effect of nitrogen and irrigation on water use, moisture extraction pattern, nutrient uptake and yield of fennel (Foeniculum vulgare). Indian J. Agron., 50: 73-76.

Ghanshyam, Dodiya, N. S., Sharma, S. P., Jain, H. K. and Dashora, A. 2015. Assessment of genetic variability, correlation and path analysis for yield and its components in ajwain (Trachyspermum ammi L.). J. Spices and Aromatic Crops, 24(1): 43-46.

Mamatha, N.C., Tehlan, S.K., Srikanth, M., Ravikumar, T., Batra. V.K., Karthik 
Reddy, P. and Manoj Kumar Nalla. 2017. Mean performance of 150 fenugreek (Trigonella foenum-graecum L.) genotypes for yield and yield contributing traits. Int. J. Pure \& App. Biosci., 5 (3): 1097-1102.

Miranldi, E. 1999. Comparison of the essential oil from ten Foeniculum vulgare Mill. samples of fruits of different origin. Flavour and Fragrance J., 14: 379-382.

Mohamed, M. A. H. and Abdu, M. 2004. Growth and oil production of fennel (Foeniculum vulgare Mill): Effect of irrigation and organic fertilization. Biological Agri. and Horti., 22: 31-39.

Patel, D.G., Patel, P.S. and Patel, I.D. 2008. Studies on variability of some morphological characters in fennel (Foeniculum vulgare Mill.), J. Spices and Aromatic Crops, 17(1):29-32.

Rawat, S. K., Sanjay, K. and Pandey, V. K., 2013. Determination of genetic variability, correlation and path analysis for yield advancement in fennel (Foeniculum vulgare Mill.). Ind. J.
Ecology, 40(2): 272-275.

Sengupta, S. K., Verma, B. K. and Naidu, A. K., 2014. Genetic variability study in fennel (Foeniculum vulgare Mill.). Int. Sci. J. 1(1): 62-64.

Singh, V. V., Singhania, D. L., Sastry, E. V. D., Sharma, K. C. and Rajput, S. S. 2004. Character association in half sib and $S_{1}$ progenies of fennel (Foeniculum vulgare Mill.). Published in National Seminar on New Perspective in Commercial Cultivation, Processing and Marketing of Seed Spices and Medicinal Plants held at S.K.N. College of Agriculture, Jobner (Rajasthan). pp. 12 .

Singh, Y. and Mittal, P. 2002. Studies on variability, heritability and scope of improvement in fennel (Foeniculum vulgare Mill.). Bioved, 13: 7-9.

Yogi, R., Meena, R. S., Kakani, R. K., Panwar, A. and Solanki, R. K. 2013. Variability of some morphological characters in fennel. Int. J. Seed Spices, 3(1): 41-43.

\section{How to cite this article:}

Telugu, R.K., S.K. Tehlan, M. Srikanth and Mamtha, N.C. 2019. Mean Performance of Fifty Genotypes of Fennel (Foeniculum vulgare Mill.) for Yield and Yield Attributing Traits. Int.J.Curr.Microbiol.App.Sci. 8(01): 387-392. doi: https://doi.org/10.20546/ijcmas.2019.801.040 